\title{
Pengembangan Perangkat Pembelajaran Melalui Model Problem Based Learning Berorientasi Kemampuan Pemecahan Masalah Matematis pada Materi Fungsi Kelas X SMA
}

\author{
Ferry Ferdianto $^{1 *}$, Frisca Shella Fadiyah ${ }^{2}$, Mohamad Dadan Sunawan ${ }^{3}$ \\ ${ }^{1,2,3}$ Universitas Swadaya Gunung Jati \\ *ferry.ugj@gmail.com
}

Diterima: Februari 2019. Disetujui: Mei 2019. Dipublikasikan: Juli 2019.

\begin{abstract}
ABSTRAK
Penelitian ini bertujuan untuk mengembangkan perangkat pembelajaran berupa RPP dan LKS berbasis Problem Based Learning pada materi fungsi untuk siswa SMA yang berorientasi pada kemampuan pemecahan masalah. Kualitas produk yang dikembangkan dinilai berdasarkan aspek kevalidan, keefektifan, dan respons siswa terhadap LKS. Prosedur pengembangan perangkat pembelajaran mengacu pada model pengembangan 4-D, yaitu Define (Pendefinisian), Design (Perancangan), Develop (Pengembangan), dan Disseminate (Penyebaran). Penulis memiliki keterbatasan waktu dan tenaga, sehingga penulisan dilakukan hingga tahap develop. Subjek penelitian ini adalah siswa kelas X MIPA 1 sebanyak 36 siswa di SMA Negeri 1 Karangwareng. Instrumen yang digunakan untuk mengukur kualitas perangkat pembelajaran yang dikembangkan adalah lembar penilaian RPP dan LKS untuk mengukur kevalidan, tes kemampuan pemecahan masalah untuk mengukur keefektifan, dan angket respon siswa terhadap LKS. Kualitas kevalidan perangkat pembelajaran memenuhi kriteria valid berdasarkan skor rata-rata RPP dari lima validator yaitu 91\% dengan kriteria sangat baik dan skor rata-rata LKS dari lima validator yaitu 92\% dengan kriteria sangat baik. Kualitas keefektifan perangkat pembelajaran memenuhi kriteria efektif berdasarkan hasil pretest dan post-test dengan peningkatan persentase ketuntasan dari $2,8 \%$ menjadi $72 \%$. Respons siswa sebesar $76 \%$ menunjukkan respons yang positif terhadap perangkat pembelajaran berupa LKS.
\end{abstract}

Kata kunci: model Problem Based Learning, kemampuan pemecahan masalah matematis.

\begin{abstract}
This study aims to develop learning tools in the form of RPP and LKS based on Problem Based Learning in the function material for high school students which is oriented to problem solving abilities. The quality of the product being developed is assessed based on the validity, effectiveness, and response of students to the LKS. The learning tool development procedure refers to the 4-D development model, namely Define, Design, Develop, and Disseminate (Distribution). Because of the limitations of the author, the writing is done up to the develop stage. The subjects of this study were 36 students of class X MIPA 1 as many as 36 students in SMAN 1 Karangwareng. The instruments used to measure the quality of learning tools developed are lesson plan assessment sheets and student worksheets to measure validity, test problem solving abilities to measure effectiveness, and questionnaires to students' responses to worksheets. Validity quality of learning devices meets valid criteria based on average RPP scores from five validators, namely $91 \%$ with very good criteria and an average score of LKS from five validators, namely $92 \%$ with very good criteria. The quality of the effectiveness of learning devices meets the effective criteria based on the results of pretest and post-test with an increase in completeness percentage from $2.8 \%$ to $72 \%$. Student responses of $76 \%$ showed a positive response to learning equipment in the form of LKS.
\end{abstract}

Keywords: Problem Based Learning, mathematical problem solving ability.

How to Cite: Ferdianto, F., Fadiyah, F. S., \& Sunawan, M. D. (2019). Pengembangan Perangkat Pembelajaran Melalui Model Problem Based Learning Berorientasi Kemampuan Pemecahan Masalah Matematis pada Materi Fungsi Kelas X SMA. Journal Of Medives : Journal Of Mathematics Education IKIP Veteran Semarang, 3(2), 165-176. 


\section{PENDAHULUAN}

Persaingan di era globalisasi ini menuntut generasi bangsa Indonesia untuk memiliki kualitas sumber daya manusia yang unggul salah satunya dalam dunia pendidikan. Kurikulum 2013 sebagai salah satu upaya pemerintah dalam penguasaan ilmu dan teknologi seperti yang digariskan dalam haluan negara. Standar isi Kurikulum 2013 menjelaskan bahwa dalam muatan matematika siswa dapat menunjukkan sikap logis, kritis, analisis, kreatif, ulet, bertanggungjawab, aktif dan mandiri, serta pantang menyerah dalam menyelesaikan permasalahan (Sulistyani \& Retnawati, 2015).

Depdiknas (Herdiana, 2017) mengemukakan tujuan yang ingin dicapai melalui pembelajaran matematika adalah: (1) memahami konsep matematika, menjelaskan keterkaitan antar konsep dan mengaplikasikan konsep atau algoritma secara luwes, akurat, efisien, dan tepat dalam pemecahan masalah; (2) menggunakan penalaran pada pola dan sifat, melakukan manipulasi matematika dalam membuat generalisasi, menyusun bukti, atau menjelaskan gagasan dan pernyataan matematika; (3) memecahkan masalah yang meliputi kemampuan memahami masalah, merancang model matematika, menyelesaikan model dan menafsirkan solusi yang diperoleh; (4) mengkomunikasikan gagasan dengan simbol, tabel, diagram, atau media lain untuk memperjelas keadaan atau masalah, dan (5) memiliki sikap menghargai kegunaan matematika dalam kehidupan, yaitu memiliki rasa ingin tahu, perhatian, dan minat dalam mempelajari matematika, serta sikap ulet dan percaya diri dalam pemecahan masalah.

Tujuan pembelajaran yang dikemukakan oleh Depdiknas mengarah pada orientasi pembelajaran matematika dengan mengasah kemampuan pemecahan masalah. Widodo (2013) mengatakan pemecahan masalah sebagai proses yang digunakan untuk menyelesaikan masalah. Masalah dapat terjadi jika seseorang tidak mempunyai aturan tertentu yang dapat dipergunakan untuk mengatasi kesenjangan antara situasi saat ini dan tujuan yang akan dicapai. Pemecahan masalah matematis yang digunakan pada penelitian ini adalah pemecahan masalah dari Polya (Widodo, 2013). Empat langkah untuk menyelesaikan masalah matematika tersebut adalah (1) memahami masalah, (2) membuat rencana, (3) melaksanakan rencana, dan (4) memeriksa kembali jawaban. Kenyataan di lapangan bahwa kemampuan pemecahan masalah matematis siswa sekolah menengah atas belum optimal. Hal ini didukung dengan penelitian yang dilakukan oleh Susanti, Musdi, \& Syarifuddin (2017) setelah melakukan observasi di SMAN 7 Padang pada tanggal 14-21 Mei 2016 mengatakan bahwa kemampuan pemecahan masalah matematis yang rendah.

Berdasarkan hasil studi PISA (Program for International Student Assessment) tentang kemampuan siswa dalam pembelajaran matematika tahun 2015 yang menunjukkan Indonesia baru bisa menduduki peringkat 69 dari 76 negara. PISA menyatakan bahwa performa siswa di Indonesia masih tergolong rendah. Supriatna 
(Wirdaningsih, Arnawa, \& Anhar, 2017) juga memberikan gambaran bahwa soalsoal kemampuan pemecahan masalah masih belum dikuasai. Selain itu, pembelajaran yang berlangsung di kelas masih terlihat siswa yang mengerjakan tugas di luar topik pembelajaran matematika.

Hasil studi pendahuluan dengan mewawancarai guru matematika kelas $\mathrm{X}$ juga mengatakan bahwa kemampuan siswa dalam memecahkan soal cerita masih rendah khususnya materi fungsi komposisi dan fungsi invers. Siswa juga belum bisa mengaplikasikan materi dalam kehidupan sehari-hari. Hal ini dikarenakan siswa lebih berfokus dengan teknik, rumus, dan penyelesaian masalah yang diberikan oleh guru.

Effendi (2012) pun mengatakan bahwa kenyataan di lapangan pembelajaran matematika masih cenderung berfokus pada buku teks, masih sering dijumpai guru matematika dengan kebiasaan mengajarnya dengan menggunakan langkah-langkah pembelajaran seperti: menyajikan materi pembelajaran, memberikan contoh soal dan meminta siswa mengerjakan soal latihan yang terdapat dalam buku teks yang mereka gunakan dalam mengajar dan kemudian membahasnya bersama siswa. Pembelajaran tersebut masih secara teacher's centered (berpusat pada guru). Kurikulum 2013 membutuhkan model pembelajaran yang dapat membuat siswa terlibat aktif saat proses pembelajaran berlangsung. Seperti yang dikatakan Lukman (2014), model Problem Based Learning (PBL) adalah model pembelajaran yang menjadikan masalah kontekstual sebagai pokok utama pembelajaran, PBL adalah sebuah strategi pembelajaran yang menarik (Ferdianto, Setiyani, \& Maharani, 2015). Proses pembelajaran model ini diawali dengan menyajikan masalah oleh guru. Selanjutnya, siswa memecahkan permasalahan secara mandiri maupun kelompok kecil, mengintegrasikan pengetahuannya untuk menyelesaikan masalah, hingga akhirnya melaporkan hasil pekerjaannya ke dalam bentuk laporan tertulis maupun presentasi. Serupa dengan penelitian yang dilakukan (Abdullah, Tarmizi, \& Abu, 2010) "it can be contended that the PBL group used the Polya's problem solving heuristic more effectively". Artinya model Problem Based Learning (PBL) menggunakan pemecahan masalah Polya lebih efektif dan dapat menumbuhkan kerja sama tim yang baik. Rohati (2013) juga menyimpulkan hasil belajar siswa yang mengikuti pembelajaran dengan menggunakan bahan ajar yang dikembangkan dengan strategi problem based learning pada siswa X-4 SMA Negeri 3 Kota Jambi memperoleh nilai rata-rata 85,1. Hal ini menunjukkan bahwa dengan model Problem Based Learning sangat efektif untuk diterapkan dalam pembelajaran Kurikulum 2013. Namun, inovasi model pembelajaran saja tidak cukup melainkan diperlukannya suatu perangkat pembelajaran seperti Silabus, RPP, dan LKS.

Permendikbud No. 65 Tahun 2013 (Abidin, 2014) tentang Standar Proses Pendidikan Dasar dan Menengah disebutkan bahwa penyusunan perangkat pembelajaran merupakan bagian dari perencanaan pembelajaran. RPP digunakan sebagai acuan dan arahan 
dalam pembelajaran agar tujuan pembelajaran tercapai. Majid (2013), Lembar Kerja Siswa (LKS) adalah perangkat pembelajaran sebagai pelengkap atau sarana pendukung pelaksanaan rencana pembelajaran. Penelitian yang dilakukan oleh (Yustianingsih, Syarifuddin, \& Yerizon, 2017) menyatakan bahwa RPP dan LKS yang dipakai oleh guru dalam pembelajaran di kelas masih terdapat kekurangan dan kesenjangan, sehingga perlu adanya pembaharuan pada perangkat pembelajaranPenggunaan perangkat pembelajaran dengan baik dan benar dapat membuat proses pembelajaran yang melibatkan siswa secara aktif. Hal itu dapat terwujud dengan mengembangkan perangkat pembelajaran berupa silabus, RPP, LKS, dan tes kemampuan pemecahan masalah dengan kualitas yang valid, efektif, dan memiliki respons siswa secara positif.

Perangkat pembelajaran dengan kualitas valid dan efektif dapat dihasilkan dengan model pengembangan yang disarankan oleh Thiagarajan, Semmel, dan Semmel yaitu model Four$D$ (4-D). Al-Tabany (2014) mengatakan perangkat pembelajaran dikembangkan dengan model pengembangan perangkat pembelajaran yang disarankan oleh Thiagarajan, Semmel, dan Semmel yaitu model 4-D, model 4-D terdiri atas tahapan Define, Design, Develop, dan Disseminate.

Hal ini didukung dengan penelitian yang dilakukan oleh Ferdianto \& Setiyani (2018) mengatakan bahwa proses pengembangan bahan ajar materi media pembelajaran berbasis kearifan lokal menggunakan model pengembang- an 4-D Thiagarajan yang dimodifikasi melalui serangkaian tahap pengembangan yakni tahap pendefinisian, perancangan, pengembangan hingga penyebaran terbatas telah dirancang suatu perangkat pembelajaran matematika berupa modul media pembelajaran berbasis kearifan lokal memenuhi kriteria valid.

Berdasarkan masalah yang telah diuraikan, pada penelitian ini penulis mengembangkan perangkat pembelajaran dengan menggunakan model pembelajaran berbasis masalah yang berorientasi pada kemampuan pemecahan masalah matematis siswa. Adapun rumusan masalah dalam penelitian ini sebagai berikut. (1) Bagaimana mengembangkan perangkat pembelajar-an berupa LKS melalui model Problem Based Learning (PBL) berorientasi kemampuan pemecahan masalah matematis pada materi fungsi kelas X SMA yang ditinjau dari aspek kevalidan; (2) Bagaimana keefektifan terhadap LKS dengan melihat hasil tes akhir (post-test) yang diperoleh siswa kelas X SMA pada materi fungsi; (3) Bagaimana respons siswa terhadap penggunaan LKS melalui model Problem Based Learning (PBL) berorientasi kemampuan pemecahan masalah matematis pada materi fungsi kelas X SMA yang telah dikembangkan.

Berdasarkan rumusan masalah di atas, maka tujuan dalam penelitian ini yaitu. (1) Mengembangkan perangkat pembelajaran matematika berupa RPP dan LKS melalui model Problem Based Learning berorientasi kemampuan pemecahan masalah matematis pada materi fungsi kelas X SMA yang sesuai 


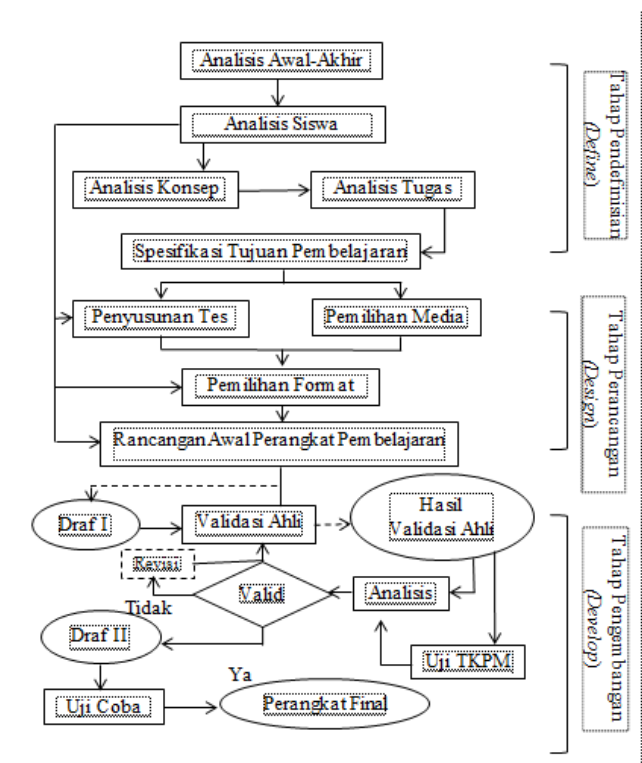

Gambar 1. Modifikasi Pengembangan Perangkat Model 4-D

dengan Kurikulum 2013 yang valid; (2) Mengetahui keefektifan terhadap LKS dengan melihat hasil pretest dan posttest yang diperoleh siswa kelas X SMA pada materi fungsi; (3) Mengetahui respons siswa terhadap perangkat pembelajaran berupa LKS melalui model Problem Based Learning berorientasi kemampuan pemecahan masalah matematis pada materi fungsi kelas X SMA yang telah dikembangkan. Penelitian berupa pengembangan perangkat pembelajaran matematika ini diharapkan dapat memberi manfaat sebagai salah satu acuan dalam kegiatan pembelajaran pada materi fungsi komposisi dan fungsi invers atau pokok bahasan lain. Selain itu, pembelajaran menjadi lebih efektif dan aktif.

\section{METODE PENELITIAN}

Penelitian ini termasuk Research and Development (R\&D). Sujadi (Rohati, 2013) mengatakan Research and Development $(\mathrm{R} \& \mathrm{D})$ adalah metode untuk menghasilkan sebuah produk baru atau menyempurnakan produk yang telah ada yang dapat dipertanggungjawabkan. Subjek penelitian ini 36 siswa kelas X MIPA 1 SMAN 1 Karangwareng. Penelitian ini akan dikembangkan perangkat pembelajaran berupa RPP dan LKS. Alur penelitian ini berdasarkan model pengembangan yang disarankan oleh Thiagarajan, Semmel, dan Semmel Al-Tabany (2014) yaitu model 4-D yang meliputi empat langkah utama yaitu Define, Design, Develop, dan Disseminate. Model pengembangan ini dimodifikasi menjadi tiga tahap diantaranya Define, Design, dan Develop. Pengembangan perangkat tersebut melalui proses validasi oleh 5 validator. Diagram alir dapat dilihat pada Gambar 1.

\section{Prosedur Penelitian}

Penelitian ini menggunakan metode Research and Development (R\&D), pada penelitian ini akan dikembangkan perangkat pembelajarn berupa Rencana Pelaksanaan 
Pembelajaran (RPP) dan Lembar Kerja Siswa (LKS) menggunakan model pengembangan yang disarankan oleh Thiagarajan, Semmel, dan Semmel adalah model 4-D. Model ini terdiri dari empat tahap pengembangan, tetapi karena keterbatasan waktu dan tenaga, maka peneliti hanya melakukan tiga tahap pengembangan yaitu Define (Pendefinisian), Design (Perancangan), Develop (Pengembangan).

\section{Tahap Define}

Tahap ini bertujuan untuk menentukan dan mendefinisikan syarat dibutuhkan dalam pembelajaran dengan menganalisis tujuan dan batasan materi. Tahapan ini meliputi: (a) analisis awalakhir bertujuan untuk menetapkan masalah dasar yang diperlukan dalam mengembangkan perangkat pembelajaran berupa LKS fungsi invers dan fungsi komposisi; (b) analisis siswa bertujuan untuk memahami karakteristik siswa yang selaras dengan rancangan perangkat pembelajaran berupa LKS yang akan dikembangkan; (c) analisis konsep bertujuan untuk mengidentifikasi, merinci, dan menyusun secara sistematis konsep-konsep mengenai materi fungsi komposisi dan fungsi invers yang akan diajarkan berdasarkan analisis awal-akhir; (d) analisis tugas merupakan pengidentifikasian keterampilan akademis utama yang diperlukan pada kurikulum dan menganalisisnya pada suatu kerangkan sub keterampilan akademis yang dikembangkan dalam pembelajaran; (e) spesifikasi tujuan pembelajaran untuk merumuskan hasil analisis tugas dan analisis konsep menjadi suatu indikator pencapaian kompetensi berdasarkan kompetensi inti dan kompetensi dasar lalu dilanjutkan menjadi tujuan pembelajaran.

\section{Tahap Design}

Setelah tahap pendefinisian selesai, selanjutnya dilakukan tahap perancangan berupa rancangan awal perangkat pembelajaran berupa LKS. Tujuan tahap ini adalah memperoleh sebuah hasil rancangan perangkat pembelajaran berupa LKS yang disesuaikan dengan model Problem Based Learning berorientasi kemampuan pemecahan masalah matematis siswa. Pada tahap ini juga akan mendapatkan sebuah hasil yang disebut Draf I. Tahap ini meliputi: (a) penyusunan tes dirancang berdasarkan hasil perumusan tujuan pembelajaran yang dilakukan pada tahap Define; (b) pemilihan media dilakukan dengan tujuan menentukan media atau peralatan yang mampu menunjang LKS dengan tepat supaya mampu menyajikan materi pembelajaran dengan baik. Pada tahap pemilihan media haruslah disesuaikan dengan analisis tugas, analisis konsep, karakteristik siswa, dan fasilitas yang disediakan di sekolah (Hartono \& Noto, 2017); (c) pemilihan format dilakukan dengan mengkaji perangkat yang sudah ada dan disesuaikan dengan pemilihan media yang disediakan oleh sekolah. Pada tahap ini penulis menggunakan Software Microsoft Word 2010 dalam merancang suatu perangkat berupa LKS; (d) desain rancangan awal LKS dengan mengumpulkan materi fungsi komposisi dan fungsi invers. Tahap selanjutnya penulis menggunakan Microsoft Word 2010 untuk mendesain LKS. 


\section{Tahap Develop}

Tahap pengembangan ini merupakan tahap terakhir pada pengembangan perangkat pembelajaran matematika berupa LKS. Pada tahap ini terdapat dua langkah kegiatan meliputi: (a) validasi perangkat pembelajaran dimaksudkan untuk mendapatkan masukan dalam revisi perangkat pembelajaran yang nanti akan diujicobakan dalam tahap berikutnya. Validasi difokuskan pada isi, format, bahasa, dan ilustrasi serta kesesuaian dengan model Problem Based Learning; (b) uji coba perangkat pembelajaran akan digunakan untuk mengetahui kelayakan dari perangkat pembelajaran yakni RPP dan LKS.

\section{Instrumen Pengumpulan dan Pengolahan Data}

Instrumen penelitian adalah suatu alat yang digunakan untuk mengetahui, menilai, dan mengukur sebuah kejadian di alam atau kejadian sosial yang akan diamati. Pada penelitian ini akan digunakan instrumen pengumpulan data, yaitu wawancara, lembar validasi perangkat pembelajaran berupa RPP dan LKS, lembar respons siswa terhadap LKS, dan Tes Kemampuan Pemecahan Masalah (TKPM).

Lembar validasi perangkat pembelajaran diberikan kepada 5 validator. Selanjutnya akan dilakukan perhitungan analisis secara keseluruhan untuk mengetahui perangkat pembelajaran melalui model Problem Based Learning (PBL) yang valid atau tidak. Menghitung skor validasi secara keseluruhan dengan rumus menurut
Akbar (Ferdianto \& Setiyani, 2018: 45)yang digunakan sebagai berikut.

$$
\begin{gathered}
V_{\text {gabungan }}=\frac{\sum V_{i}}{n} \\
V_{\text {gabungan }}=\text { hasil validasi; } \sum V_{i}=\text { jumlah }
\end{gathered}
$$
skor dari tiap validator; $n=$ jumlah validator.

Kemudian hasil dari keseluruhan penilaian validator diinterpretasikan berdasarkan Tabel 1 berikut.

Tabel 1. Interpretasi Hasil Validasi

\begin{tabular}{ccl}
\hline No. & Kriteria Validasi & \multicolumn{2}{c}{ Tingkat Validasi } \\
\hline 1. & $85,01 \%<\mathrm{V} \leq 100 \%$ & $\begin{array}{l}\text { Sangat valid atau dapat } \\
\text { digunakan tanpa revisi. }\end{array}$ \\
2. & $70,01 \%<\mathrm{V} \leq 85 \%$ & $\begin{array}{l}\text { Valid atau dapat } \\
\text { digunakan perlu revisi } \\
\text { kecil. }\end{array}$ \\
3. & $50,01 \%<\mathrm{V} \leq 70 \%$ & $\begin{array}{l}\text { Kurang valid atau } \\
\text { disarankan tidak } \\
\text { dipergunakan karena } \\
\text { perlu revisi besar. } \\
\text { Tidak valid atau tidak } \\
\text { boleh dipergunakan. }\end{array}$ \\
\hline
\end{tabular}

Analisis keefektifan bertujuan untuk mengetahui keefektifan perangkat pembelajaran berupa LKS yang telah dikembangkan Via (2015). Sejalan dengan Zeila, Hobri, \& Suharto (2014), keefektifan perangkat pembelajaran dapat diukur dari persentase aktivitas siswa pada saat pembelajaran, respons siswa, dan nilai yang diperoleh siswa pada tes akhir (posttest). Suryaningtyas (2014) mengatakan bahwa perangkat pembelajaran dikatakan efektif apabila memperoleh hasil dari tes akhir (posttest) mencapai nilai KKM (Kriteria Ketuntasan Minimal) $\geq 78$ yang telah ditentukan oleh pihak sekolah.

Pada penelitian ini apabila respons siswa terhadap perangkat pembelajaran menunjukkan respons positif pada pernyataan yang memiliki makna positif 
dengan kategori sangat baik dan baik sesuai pada Tabel 2.

$$
p=\frac{\text { jumlah siswa yang tuntas }}{\text { jumlah siswa }} \times 100
$$

Tabel 2. Kriteria Ketuntasan Belajar

\begin{tabular}{ccc}
\hline No & $\begin{array}{c}\text { Persentase } \\
\text { Ketuntasan }\end{array}$ & Kriteria \\
\hline 1 & $p>80$ & Sangat Baik \\
2 & $60<p \leq 80$ & Baik \\
3 & $40<p \leq 60$ & Cukup \\
4 & $20<p \leq 40$ & Kurang \\
\hline \multicolumn{3}{c}{ dimodifikasi Widoyoko (2009) }
\end{tabular}

\section{HASIL DAN PEMBAHASAN}

\section{Analisis Kevalidan Perangkat Pembelajaran}

\begin{tabular}{lrr}
\multicolumn{1}{c}{ Hasil } & validasi & \multicolumn{2}{c}{ perangkat } \\
pembelajaran & diperoleh & dari lima \\
validator di & antaranya & tiga dosen \\
pendidikan matematika & Universitas
\end{tabular} Swadaya Gunung Jati Cirebon dan dua guru matematika SMAN 1 Karangwareng.

Tabel 3. Rekapitulasi Validasi RPP

\begin{tabular}{cccc}
\hline \multirow{2}{*}{$\begin{array}{c}\text { Kode } \\
\text { Validator }\end{array}$} & $\begin{array}{c}\text { Skor } \\
\text { yang } \\
\text { Dicapai }\end{array}$ & $\begin{array}{c}\text { Skor } \\
\text { Maksimal }\end{array}$ & $\begin{array}{c}\text { Kriteria } \\
(\%)\end{array}$ \\
\hline V-1 & 90 & & $90 \%$ \\
V-2 & 95 & & $95 \%$ \\
V-3 & 90 & 100 & $90 \%$ \\
V-4 & 86 & & $86 \%$ \\
V-5 & 96 & & $96 \%$ \\
\hline \multicolumn{3}{c}{$V_{\text {gabungan }}$} & $\mathbf{9 1 \%}$ \\
\hline
\end{tabular}

Berdasarkan Tabel 3 rekapitulasi validasi perangkat pembelajaran berupa RPP memperolah hasil 91\%, maka perangkat pembelajaran berupa RPP dikategorikan sangat valid atau dapat digunakan tanpa revisi.
Tabel 4. Rekapitulasi Validasi Perangkat Pembelajaran

\begin{tabular}{cccc}
\hline \multirow{2}{*}{$\begin{array}{c}\text { Kode } \\
\text { Validator }\end{array}$} & $\begin{array}{c}\text { Skor } \\
\text { yang } \\
\text { Dicapai }\end{array}$ & $\begin{array}{c}\text { Skor } \\
\text { Maksimal }\end{array}$ & $\begin{array}{c}\text { Kriteria } \\
(\%)\end{array}$ \\
\hline V-1 & 110 & & $91,6 \%$ \\
V-2 & 106 & & $88 \%$ \\
V-3 & 107 & 120 & $89 \%$ \\
V-4 & 119 & & $99,2 \%$ \\
V-5 & 108 & & $90 \%$ \\
\hline \multicolumn{3}{|l}{$\boldsymbol{V}_{\text {gabungan }}$} & $\mathbf{9 2 \%}$ \\
\hline
\end{tabular}

Berdasarkan Tabel 4, rekapitulasi validasi perangkat pembelajaran berupa LKS memperolah hasil 92\%, maka perangkat pembelajaran berupa LKS dikategorikan sangat valid atau dapat digunakan tanpa revisi.

Serupa dengan penelitian yang dilakukan oleh Zeila dkk., (2014) perangkat pembelajaran yang dikembangkan harus memenuhi kriteria kualitas perangkat yang baik salah satunya kriteria kevalidan dianalisis dari draft I sebagai hasil dari tahap desain atau perancangan, sebuah perangkat dikatakan valid jika nilai validitas dari perangkat tersebut lebih dari $60 \%$ atau dengan kategori tinggi. Seperti yang dikatakan Pariska (2012) LKS yang baik harus mampu mendorong partisipasi aktif siswa, dan mengembangkan budaya membaca dan menulis.

\section{Analisis Keefektifan Perangkat Pembelajaran}

Keefektifan suatu perangkat pembelajaran dilihat dari hasil tes kemampuan pemecahan masalah. Perangkat pembelajaran dikatakan efektif apabila hasil dari tes kemampuan pemecahan masalah mencapai nilai $\mathrm{KKM} \geq 78$ yang telah ditentukan oleh 
pihak sekolah. Hal ini sejalan dengan Rohati (2013) mengemukakan bahwa bahan ajar yang dikembangkan dengan strategi problem based learning dikatakan cukup efektif dengan melihat hasil belajar dan aktivitas siswa.

Tes awal (pretest) diberikan kepada siswa kelas X MIPA 1 sebanyak 36 siswa. Hasil dari tes awal (pretest) menunjukkan bahwa persentase ketuntasan belajar sebesar 2,8\%, dimana siswa yang tuntas sebanyak 1 siswa dan tidak tuntas sebanyak 35 siswa. Sedangkan hasil tes akhir menunjukkan persentase ketuntasan belajar sebesar $72 \%$, dimana siswa yang tuntas sebanyak 26 siswa dan tidak tuntas sebanyak 10 siswa.

\section{Analisis Respons Siswa}

Analisis respons siswa terhadap perangkat pembelajaran berupa LKS yang diujikan kepada 36 siswa kelas $\mathrm{X}$ MIPA 1, dimana siswa kelas X MIPA 1 memiliki kemampuan matematis yang heterogen. Menghitung persentase jawaban siswa untuk masing-masing item pernyataan dengan frekuensi jawaban siswa pada tiap kriteria skor $4=$ sangat setuju; 3 setuju; 2 tidak setuju; dan 1 sangat tidak setuju, selanjutnya dimasukkan ke dalam persamaan

$$
P=\frac{f}{n} \times 100 \% \text {. }
$$

Hasil rekapitulasi respons siswa terhadap LKS dengan jumlah sebanyak 36 siswa memiliki respons yang positif. Hal ini dapat dilihat dari hasil perhitungan respons siswa suatu perangkat pembelajaran berupa LKS dengan memperoleh persentase respons sebesar $76 \%$ dengan kategori positif. Artinya, hampir seluruh siswa kelas $\mathrm{X}$
MIPA 1 menunjukkan respons yang positif terhadap perangkat pembelajaran berupa LKS. Sedangkan respons siswa memperoleh persentase respons sebesar $24 \%$ dengan kategori negatif. Artinya, sebagian kecil siswa kelas X MIPA 1 menunjukkan respons yang negatif terhadap perangkat pembelajaran berupa LKS. Seperti penelitian yang dilakukan oleh Via (2015) menyimpulkan bahwa respons siswa dikatakan mempunyai respons positif jika rata-rata persentase respons siswa lebih dari $75 \%$.

Berdasarkan uraian di atas, respons siswa terhadap LKS memiliki respons yang positif. Hal ini dikarenakan hasil perhitungan respons siswa suatu perangkat pembelajaran berupa LKS dengan memperoleh persentase respons sebesar $76 \%$ dengan kategori positif. Artinya, hampir seluruh siswa kelas $\mathrm{X}$ MIPA 1 menunjukkan respons yang positif terhadap perangkat pembelajaran berupa LKS sesuai dengan kebutuhan siswa kelas X MIPA 1.

\section{PENUTUP}

\section{Simpulan}

Berdasarkan hasil penelitian dan pembahasan, penulis akan menyimpulkan beberapa hal yakni: (1) hasil validasi RPP memperoleh persentase secara keseluruhan sebesar $91 \%$ dari lima validator, sedangkan validasi LKS memperoleh persentase sebesar 92\%. dari lima validator Perangkat pembelajaran tersebut menunjukkan kriteria sangat valid dan dapat digunakan dalam kegiatan pembelajaran; (2) analisis keefektifan perangkat pembelajaran ini ditinjau dari hasil tes akhir (post-test), dimana siswa telah menerima 
materi fungsi komposisi dan fungsi invers. Keefektifan perangkat pembelajaran berupa tes kemampuan pemecahan masalah dikatakan baik, sebab memperoleh persentase ketuntasan belajar secara klasikal sebesar $72 \%$; (3) hasil respons siswa terhadap LKS diperoleh dengan rata-rata presentase $76 \%$, maka dapat dinyatakan bahwa nilai respons siswa secara klasikal menunjukkan respons yang positif terhadap LKS.

\section{Saran}

Saran yang dapat diberikan berdasarkan penelitian yang telah dilakukan adalah yakni (1) Perangkat pembelajaran berupa LKS berbasis Problem Based Learning berorientasi kemampuan pemecahan masalah matematis pada materi fungsi kelas $\mathrm{X}$ SMA yang telah dikembangkan diharapkan dapat digunakan di sekolahsekolah yang memiliki karakteristik yang sama dengan sekolah yang menjadi tempat dilakukannya uji coba lapangan perangkat pembelajaran; (2) perangkat pembelajaran berupa LKS yang dikembangkan memiliki kriteria valid, efektif, dan respons siswa yang positif. Oleh karena itu, bagi penulis lain dapat melakukan pengembangan perangkat pembelajaran serupa sesuai dengan prosedur, materi pembelajaran, dan model pembelajaran yang lain; (3) penelitian ini hanya sampai pada tahap develop, maka penulis menyarankan bagi penulis lain untuk melanjutkan pada tahap disseminate/dengan uji coba perangkat pembelajaran di sekolahsekolah lain dengan jenjang yang sama.

\section{DAFTAR PUSTAKA}

Abdullah, N. I., Tarmizi, R. A., \& Abu, R. (2010). The Effects of Problem Based Learning on Mathematics Performance and Affective Attributes in Learning Statistics at Form four Secondary Level. Procedia-Social and Behavioral Sciences, 8, 370-376.

Abidin, Y. (2014). Desain Sistem Pembelajaran Dalam Konteks Kurikulum 2013. Refika Aditama.

Al-Tabany, T. I. B. (2014). Mendesain Model Pembelajaran Inovatif, Progresif, dan Kontekstual. Jakarta: Prenadamedia Group.

Effendi, L. A. (2012). Pembelajaran Matematika dengan Metode Penemuan Terbimbing Untuk Meningkatkan Kemampuan Representasi Dan Pemecahan Masalah Matematis Siswa SMP. Jurnal Penelitian Pendidikan, 13(2), $1-10$.

Ferdianto, F., \& Setiyani, S. (2018). Pengembangan Bahan Ajar Media Pembelajaran Berbasis Kearifan Lokal Mahasiswa Pendidikan Matematika. JNPM (Jurnal Nasional Pendidikan Matematika), 2(1), 3747.

Ferdianto, F., Setiyani, S., \& Maharani, A. (2015). Uji Komparasi Antara Kemampuan Penalaran Matematis Mahasiswa yang Berasal Dari Lulusan Sma IPA dan Bukan IPA Pada Mata Kuliah Kalkulus III Di Unswagati Cirebon. Euclid, 2(1).

Hartono, W., \& Noto, M. S. (2017). Pengembangan Modul Berbasis Penemuan Terbimbing Untuk Meningkatkan Kemampuan Matematis Pada Perkuliahan Kalkulus Integral. JNPM (Jurnal 
Nasional Pendidikan Matematika), 1(2), 320-333.

Herdiana, Y. (2017). Perbandingan Pemecahan Masalah Matematis Siswa Antara Discovery Learning Dan Problem Based Learning. KALAMATIKA Jurnal Pendidikan Matematika, 2(2), 131-146.

Lukman, H. S. (2014). Implementasi Model Problem-Based Learning Untuk Meningkatkan Kemampuan Metakognitif Dan Self-Regulated Learning Siswa Sma: Penelitian Kuasi Eksperimen pada Salah Satu Sekolah Menengah Atas di Kota Sukabumi (PhD Thesis). Universitas Pendidikan Indonesia.

Majid, A. (2013). Strategi pembelajaran. Bandung: PT Remaja Rosdakarya.

Pariska, I. S. (2012). Pengembangan Lembar Kerja Siswa Matematika Berbasis Masalah. Journal Pendidikan Matematika UNP, 1(1).

Rohati, R. (2013). Pengembangan Bahan Ajar Materi Sistem Persamaan Linear dengan Strategi Problem Based Learning untuk Kelas X SMA. EDUMATICA| Jurnal Pendidikan Matematika, 3(2), 26-34.

Sulistyani, N., \& Retnawati, H. (2015). Pengembangan Perangkat Pembelajaran Bangun Ruang di SMP dengan Pendekatan Problem-Based Learning. jurnal riset pendidikan matematika, 2(2), 197-210.

Suryaningtyas, W., \& Shoffan. (2014). Pengembangan Perangkat Pembelajaran "Busaka" (Buku Saku Statistika) dengan Model 4DThiagarajan. Seminar Nasional
Pendidikan Matematika Ahmad Dahlan (SENDIKMAD 2014).

Susanti, Musdi, E., \& Syarifuddin, H. (2017). Pengembangan Perangkat Pembelajaran Matematika Materi Statistik Berbasis Penemuan Terbimbing Untuk Meningkatkan Kemampuan Pemecahan Masalah Matematis Materi Statistika. Jurnal JNPM (Jurnal Nasional Pendidikan Matematika), 1(2), 305-319.

Via, Y. (2015). Peningkatan Kemampuan Pemecahan Masalah Melalui Pengembangan Lembar Kegiatan Siswa (LKS) dengan Pendekatan Saintifik. Wahana, 64(1), 49-57.

Widodo, S. A. (2013). Analisis kesalahan Dalam Pemecahan Masalah Divergensi Tipe Membuktikan Pada Mahasiswa Matematika. Jurnal pendidikan dan pengajaran, 46(2 Juli).

Widoyoko, E. P. (2009). Evaluasi program pembelajaran (Vol. 91). Yogyakarta: Pustaka Pelajar.

Wirdaningsih, S., Arnawa, I. M., \& Anhar, A. (2017). Pengembangan Perangkat Pembelajaran Matematika dengan Pendekatan Contextual Teaching and Learning untuk Meningkatkan Kemampuan Pemecahan Masalah Peserta Didik Kelas XI. JNPM (Jurnal Nasional Pendidikan Matematika), 1(2), 275289.

Yustianingsih, R., Syarifuddin, H., \& Yerizon, Y. (2017). Pengembangan Perangkat Pembelajaran Matematika Berbasis Problem Based Learning (PBL) untuk Meningkatkan Kemampuan Pemecahan Masalah Peserta Didik Kelas VIII. JNPM 
(Jurnal Nasional Pendidikan

Matematika), 1(2), 258-274.

Zeila, W. Z., Hobri, H., \& Suharto, S. (2014). Pengembangan Perangkat Pembelajaran Matematika Berbantuan Komik POP UP dengan Model Problem Based Instruction (PBI) Sub Pokok Bahasan Kubus dan Balok Untuk Siswa SMP Kelas VIII. KadikmA, 5(3). 